\title{
Business Friendliness, Firm Performance and Owner's Optimism
}

http://doi.org/10.21272/fmir.4(3).13-23.2020.

Halil D. Kaya, ORCID: https://orcid.org/0000-0002-7535-9857

Professor of Finance, Department of Accounting and Finance, College of Business and Technology, Northeastern State University, USA

\begin{abstract}
In this study, we attempt to find the factors that influence small business owners' optimism as well as their company's success. For this purpose, we use a survey done by Kauffman foundation. This survey asks business owners about their state's performance in areas like "ease of starting a business", "ease of hiring", "regulations", and "training and networking programs". It also asks business owners questions about their firm's performance and their optimism for the future. We run several tests to see if business owners are more optimistic and more successful in states with a high score in each "business friendliness" area. We show that, in the states with a higher business friendliness composite score, both growth in revenue and growth in employees are higher and also owners tend to be more encouraging to others. Regression analyses support these findings (except for growth in employees). Our results indicate that growth in revenue is driven mainly by the Ease of Start score. In other words, the revenues of small businesses grow faster in the states with a better initial registration/establishment process. Our results also indicate that growth in the number of employees is driven mainly by the Overall Regulations score. In other words, small businesses grow faster (in terms of the number of employees) in the states with more favorable regulations. With respect to whether or not the owners would encourage others to start a business in their state, our results show that all subcomponents (Ease of Start, Ease of Hire, Overall Regulations, and Training and Networking programs) are important. The owners are more encouraging to others when Ease of Start, Ease of Hire, Overall Regulations, and Training and Networking programs are all favorable. Overall, we conclude that while all components of business friendliness have a positive relation with the small business owners' optimism, the link between the business friendliness score and firm performance is weaker. Ease of Start is important for growth in revenues and optimism, Ease of Hire is important for optimism only, Overall Regulations are important for growth in the number of employees and optimism, and Training and Networking Programs are crucial for optimism.
\end{abstract}

Keywords: regulations, business friendliness, small business, entrepreneurship, firm performance.

JEL Classification G38, L25, L26.

This work is licensed under a Creative Commons Attribution 4.0 International License

Cite as: Kaya, H. D. (2020). Business Friendliness, Firm Performance and Owner's Optimism. Financial Markets, Institutions and Risks, 4(3), 13-23. http://doi.org/10.21272/fmir.4(3).13-23.2020.

(C) The Author, 2020. This article is published with open access at Sumy State University.

\section{Introduction}

Previous studies have shown that institutional framework, regulations, and taxation significantly affect entrepreneurial activity and firm performance. Several studies (Deakins et al. (2016), Wennekers and Thurik (1999), Aidis, et. al. (2008), Smallbone, et. al. (2010), and Stephan and Uhlaner (2010), Chambers, et. al. (2018), Bailey and Thomas (2017), Douglas and Pejoska (2017), Peck et al. (2018)) show that institutional framework and regulations are important for new business formation and firm growth. Taxation is also found to have a significant impact on entrepreneurship (Bitzenis and Nito (2005), and Acs, et. al. (2009)).

While these studies have already established the relationship between regulations/institutional framework and entrepreneurship, in this current study, we go deeper and examine several different aspects of a state's business friendliness (overall business friendliness, ease of start, ease of hire, regulations, and training and networking) on small businesses' revenues, size and on owners' optimism regarding their business. In this study, we examine two issues: First, we examine the relation between each U.S. (i.e. United States) state's "business friendliness" score and the performance of the local small businesses. Then, we look into the impact of each U.S. state's "business friendliness" score on small firm owners' optimism for the future. We hope to provide each state's officials with guidance regarding how to improve the environment for small firms in their state. 
The data from the "Small Business Friendliness Survey" which was done by Kauffman Foundation and Thumptack.com in 2013 is used. The survey asks small business owners their opinions on "ease of start", "ease of hire", "overall regulations", and "training and networking opportunities" in their state. It also asks respondents questions on the growth of their business and on how optimistic they are for the future. For each state, there is a score for "ease of start", "ease of hire", "overall regulations", and "training and networking opportunities". For each state, we also compute the average response score for owners' growth expectation and owner's optimism. Therefore, in the end, each state has a score on "ease of start", "ease of hire", "overall regulations", and "training and networking opportunities", as well as on owners' growth expectation and owner's optimism.

First, the impact of the "ease of start", "ease of hire", "overall regulations", and "training and networking opportunities" scores for each state on small business owners' growth expectation in each state is examined. As measures of owners' growth expectation, we use two key statistics: "growth in revenues" and "growth in number of employees". Knowing which factor affects firm growth should be helpful to state and local authorities in forming and implementing their strategies. We aim to answer the following question: Which of these factors (i.e. "ease of start", "ease of hire", "overall regulations", and "training and networking opportunities") matter or matter the most? If, for example, "ease of start" and "ease of hire" have a significant impact on firms' growth in a state, then states will need to focus on improving those areas. Second, we examine the impact of these variables (i.e. "ease of start", "ease of hire", "overall regulations", and "training and networking opportunities") on small business owners' optimism for the future. As proxies for owner's optimism, business owners' responses on questions related to their state and local governments' support are used. We also look at whether or not individual owners encourage other potential entrepreneurs to start a business in their state. So, whether they would encourage others or not is our third optimism measure. Here, we aim to answer the following question: Which of these factors (i.e. "ease of start", "ease of hire", "overall regulations", and "training and networking opportunities") affect owner's optimism the most? Nawaser et al. (2011) contend that optimism is important for business owners because it affects how they run their business and whether they would encourage others or not. Section 2 discusses the previous literature. Section 3 details the data and the methodology used in this study. Section 4 shows the results and Section 5 includes the concluding remarks.

\section{Literature Review}

The literature on the impact of institutional framework and regulations on small businesses is extensive. Several studies show that institutional framework as a whole is important for new business formation and firm growth. Wennekers and Thurik (1999) argue that culture and institutional framework, as well as technological, demographic and economic forces are all important factors impacting entrepreneurial activity. Aidis, et. al. (2008) argue that the institutional environment in Russia explain its relatively low levels of entrepreneurship development. Manolova, et. al. (2008) contend that comparisons of the overall institutional framework across countries should be used with caution. Smallbone, et. al. (2010) show that governments create the institutional framework for entrepreneurship therefore they are important. Stephan and Uhlaner (2010) conclude that the existence of opportunities for entrepreneurs and the quality of formal institutions both increase entrepreneurial activity. Manolova, et. al. (2008) contend that comparisons of the overall institutional framework across countries should be used with caution. Deakins, et. al. (2016) show that for rural entrepreneurs, their relationship with the market environment, with the institutional regulatory environment and with the national cooperatives are each important. They show that entrepreneurs' capabilities to manage regulation are different from each other because of their relationships within each of these areas.

Other studies examine the relationship between regulations and entrepreneurship more directly. These studies show that regulations significantly affect new firm formation and firm growth. Gartner and Shane (1995) show that values, attitudes, technology, and government regulations all have a significant influence on entrepreneurship. Later, Klapper, et. al. (2006) focus on the effect of market entry regulations on the creation of new limited-liability firms, the growth of incumbent firms, and the average size of entrants. They show that regulations deter the formation of new firms. Aidis, et. al. (2007) study the impact of rules and regulations on female business development. They also look at the impact of the informal institutions such as gendered norms and values on female business startups. The authors conclude that even though women are permitted to start their own businesses, gendered norms and values restrict their activities and their access to resources. Acs and Szerb (2007) show that middle-income countries need to focus on increasing human capital, improving 
technology availability, and promoting business development. According to the authors, developed countries should reduce entry regulations and reform their labor markets as well as deregulate their financial markets. Van Stel, et. al. (2007) show that in countries where the minimum capital requirement is higher, entrepreneurship rate is lower. A second conclusion is that labor market regulations also negatively affect entrepreneurship rates. Parker (2007) shows that legal structures shape organizational forms in entrepreneurship. Regulations, bankruptcy legislation, and the broad area of property rights, efficiency of courts, and corruption are also important for entrepreneurship. Sobel, et. al. (2007) contend that while entrepreneurs initially benefit from unrestricted free entry into markets, after they enter the markets, they have an incentive to lobby for entry restrictions. Nyström (2008) argues that the size of the government sector, the security of property rights, the quality of legal structure, and the level of regulations regarding credit, business and labor significantly affects entrepreneurial activity. Constanta (2019) explains that government support is crucial for the tourism companies in Romania. Nawaser, et. al. (2011) argue that laws, regulations and motivational factors are the obstacles for entrepreneurship development. Furthermore, according to Dreher and Gassebner (2013), the number of procedures required to start a business and minimum capital requirements negatively affect entrepreneurship. Valdez and Richardson (2013) argue that values, beliefs, and abilities may be more important for entrepreneuship than economic considerations of opportunity and transaction costs. Branstetter, et. al. (2014) show that the reform in Portugal resulted in increased firm formation and employment, but mostly among "marginal firms" that would have been most readily deterred by existing heavy entry regulations. Ghani, et. al. (2014) examine the determinants of entrepreneurship in India. They contend that physical infrastructure quality and local education levels play the most significant roles in promoting entry. They also show that while strict labor regulations discourage entrepreneurship, better household banking environments improve entry.

Among the more recent papers, García-Posada and Mora-Sanguinetti (2015) report that while higher judicial efficacy increase the entry rate of firms, it has no effect on the exit rate. Peck, et. al. (2018) examine how regulations affect growth-oriented small and micro businesses in England. They show that while regulations burden these firms heavily, in order to create an advantage, some of these firms have been proactive in seeking regulatory knowledge. They state that networking is important for these firms. Douglas and Pejoska (2017) survey small businesses and find that small businesses are more heavily burdened by regulations when compared to larger businesses. They suggest a tiered regulatory approach where larger businesses will have a larger burden. They suggest governments to reduce the burden and to make compliance easier. Bailey and Thomas (2017) find that regulations deter new firm formation and therefore cause slower employment growth. They argue that larger firms may want more regulations to deter formation or growth of small businesses. Chambers, et. al. (2018) find that a 10 percent increase in regulations in an industry is associated with a 0.5 percent decrease in the number of small firms in that industry. They show that a similar increase in regulations does not affect the number of large firms in that industry. They also show that the negative impact on small businesses grow if regulations increase over time.

While all of these studies have shown that institutional environment and regulations significantly affect entrepreneurship, several other studies including Bitzenis and Nito (2005), Ovaska and Sobel (2005), and Acs, et. al. (2009) focus on the impact of taxation on entrepreneurship. These studies show that higher tax rates negatively affect entrepreneurship. Bitzenis and Nito (2005) show that the most important obstacles faced by entrepreneurs in Albania are changes in taxation procedures, unfair competition, lack of financial resources and problems related to public order. Ovaska and Sobel (2005) determine that, in post-socialist countries, contract enforcement, credit availability, low government corruption, high foreign direct investment, low regulations and taxes, and sound monetary policy are all important factors for entrepreneurial activity. Acs, et. al. (2009) scrutinize risk aversion, bureaucratic constraints, taxes, legal restrictions, and labor market rigidities. They conclude that greater regulation, administrative burden and market intervention by government all have a negative impact on entrepreneurial activity.

To summarize, several studies (Deakins et al. (2016), Wennekers and Thurik (1999), Aidis, et. al. (2008), Smallbone, et. al. (2010), and Stephan and Uhlaner (2010)) show that institutional framework as a whole is important for new business formation and firm growth. Many other studies like Chambers, et. al. (2018), Bailey and Thomas (2017), Douglas and Pejoska (2017), Peck et al. (2018), and others focus mainly on regulations. These papers show that regulations significantly affect new business formation as well as firm growth. Taxation is also found to have a significant impact on entrepreneurship (Bitzenis and Nito (2005), and Acs, et. al. (2009)).

In the next section, we go over our data and methodology. 


\section{Data and Methodology}

The survey collects information on how business friendly each U.S. state is. It asks questions on "ease of starting a business", "ease of hiring", "overall regulations", and "training \& networking programs". Then, using these responses, the survey calculates an "overall score" for business friendliness for each state. The survey also asks questions on the past and expected growth of the firm, on whether they feel their government is supporting them, and on whether they would encourage others to start a business in their state. Our main objective in this study is to see how a state's "overall score" on business friendliness as well as its components (i.e. "ease of starting a business", "ease of hiring", "overall regulations", and "training \& networking programs") affect firm performance and owners' optimism in that state.

The variables that we use in this study are explained below:

Overall business friendliness and its components:

$>$ "Overallscore": each state's overall business friendliness score as computed by the survey

$>$ "Easeofstart": each state's ease of start score as shown in the survey

$>$ "Easeofhire": each state's ease of hire score as shown in the survey

$>$ "Overallreg": each state's overall regulations score as shown in the survey

$>$ “Trainingnetworking": each state's training \& networking score as shown in the survey

Firm performance variables:

$>$ "Growthinrevenue": each state's score on the question "Over the past 12 months, did your company's revenues increase or decrease?" The answers ranged from "decreased a lot" (which we coded as "0") to "increased a lot" (which we coded as "4").

$>$ "Growthinemployees": each state's score on the question "How do you expect the number of employees at your company to change in the next 12 months?" The answers ranged from "decreased a lot" (which we coded as "0") to "increased a lot" (which we coded as "4").

Owners' optimism variables:

$>$ "Stategovsupport": each state's score on the perceived support given to startups. Individual responses ranged from very unsupportive (which we coded as " 0 ") to very supportive (which we coded as "4").

$>$ "Localgovsupport": the local government's score on the perceived support given to startups within each state. Individual responses ranged from very unsupportive (which we coded as "0") to very supportive (which we coded as "4").

$>$ "Encourageothers": each state's score on the question "Would you discourage or encourage someone from starting a new business where you live?" The answers ranged from "highly discourage" (which we coded as "0") to "highly encourage" (which we coded as "4").

It is important to note that each state's scores on "ease of starting a business", "ease of hiring", "overall regulations", and "training and networking programs" are available in the survey as a letter score. The survey uses letter grades like A+, A, A-, B+, and so on. I convert these letter grades into numbers: A+ becomes 12; A becomes 11, and so on. The lowest letter grade is F. After the conversion, F becomes 1.

As mentioned earlier, we focus on the growth in revenues, the growth in the number of employees, and whether the owners encourage others to start a business. Our hypotheses are as follows:

Hypothesis 1: Small businesses in more business-friendly states have a higher growth rate in revenues.

Hypothesis 2: Small businesses in more business-friendly states have a higher growth rate in the number of employees.

\section{Hypothesis 3: Small business owners in more business-friendly states are more encouraging to others.}

In order to do the analyses, I run nonparametric tests (i.e. Mann-Whitney-Wilcoxon tests) that compare states with high- and low-scores in each of the business friendliness category (i.e. Overallscore, Easeofstart, Easeofhire, Overallreg, and Trainingnetworking) with respect to the firm performance and owners' optimism variables. To divide between high- and low- score states in each of these categories, I use the mean values. The states with scores higher than the mean are classified as high-score states, and the states with scores lower than the mean are classified as low-score states (i.e. high-overallscore states versus low-overallscore states, high-easeofstart score states versus low-easeofstart score states, and so on). 
After running nonparametric tests, I run regressions. For the regressions, I use the following models:

Growthinre venue $=c_{0}+c_{1}$ Highschool orlower $+c_{2}$ Ageunderth irtyfive $+c_{3}$ Female

$+c_{4}$ Pr imary $+c_{5}$ Pr eviousentr $e+c_{6}$ Ageofbusfi veormore $+c_{7}$ Mostlocal

$+c_{8}$ Overallsco re $+\varepsilon_{t}$

Growthinem ployees $=c_{0}+c_{1}$ Highschool orlower $+c_{2}$ Ageunderth irtyfive $+c_{3}$ Female

$+c_{4} \operatorname{Pr}$ imary $+c_{5} \operatorname{Pr}$ eviousentr $e+c_{6}$ Ageofbusfi veormore $+c_{7}$ Mostlocal

$+c_{8}$ Overallsco re $+\varepsilon_{t}$

Encourageo thers $=c_{0}+c_{1}$ Highschool orlower $+c_{2}$ Ageunderth irtyfive $+c_{3}$ Female

$+c_{4}$ Pr imary $+c_{5} \operatorname{Pr}$ eviousentr $e+c_{6}$ Ageofbusfi veormore $+c_{7}$ Mostlocal

$+c_{8}$ Overallsco re $+\varepsilon_{t}$

Where for each state, "Highschoolorlower" is the percentage of owners that did not go to any college (4-year, technical, or community college), "Ageunderthirtyfive" is the percentage of owners that are younger than thirty-five years of age, "Female" is the percentage of owners that are female, "Primary" is the percentage of owners that have their business as their primary employment, "Previousentre" is the percentage of owners that have at least one previous entrepreneurial experience, "Ageofbusfiveormore" is the percentage of firms that are established five or more years ago, "Mostlocal" is the percentage of firms that have more than $90 \%$ of its sales within 50 miles of the firm, and "Overallscore" is the overall business friendliness score of each state.

Table 1 shows the summary statistics for our variables. As shown in the table, the highest business friendliness component score is the score for "Trainingnetworking" (i.e. 7.17), and the lowest component score is the score for "Easeofstart" (i.e. 6.93). These scores are out of a maximum score of 12. These numbers indicate that the respondents gave the highest score to (i.e. were the happiest with) the training and networking opportunities and the lowest score to (i.e. were the least happy with) the easiness of starting a business in their state. The overall score is also 6.93 .

Table 1. Summary Statistics (All Variables in \%)

\begin{tabular}{|l|c|c|c|c|c|}
\hline \multicolumn{1}{|c|}{ Variable } & Mean & Median & Stdev & Min & Max \\
\hline Highschoolorlower & 17.85 & 17.71 & 5.13 & 4.76 & 34.09 \\
\hline Ageunderthirtyfive & 20.82 & 20.31 & 5.98 & 5.26 & 38.71 \\
\hline Female & 37.00 & 36.96 & 5.96 & 21.05 & 52.94 \\
\hline Primary & 71.96 & 72.83 & 6.44 & 52.63 & 84.21 \\
\hline Previousentre & 43.84 & 43.33 & 6.78 & 29.49 & 57.14 \\
\hline Ageofbusfiveormore & 58.46 & 57.50 & 7.74 & 45.74 & 84.21 \\
\hline Mostlocal & 87.66 & 88.24 & 6.02 & 65.00 & 100.00 \\
\hline Overallscore & 6.93 & 7.00 & 3.51 & 1.00 & 12.00 \\
\hline Easeofstart & 6.93 & 7.00 & 3.51 & 1.00 & 12.00 \\
\hline Easeofhire & 7.02 & 7.00 & 3.54 & 1.00 & 12.00 \\
\hline Overallreg & 6.98 & 7.00 & 3.47 & 1.00 & 12.00 \\
\hline Trainingnetworking & 7.17 & 8.00 & 3.29 & 1.00 & 12.00 \\
\hline Growthinrevenue & 2.08 & 2.10 & 0.16 & 1.77 & 2.46 \\
\hline Growthinemployees & 2.14 & 2.13 & 0.10 & 1.86 & 2.40 \\
\hline Encourageothers & 2.74 & 2.76 & 0.22 & 2.20 & 3.14 \\
\hline Stategovsupport & 2.42 & 2.43 & 0.23 & 1.96 & 2.92 \\
\hline Localgovsupport & 2.54 & 2.57 & 0.20 & 2.00 & 2.97 \\
\hline
\end{tabular}

Source: Author's own work.

\section{Empirical Results}

Table 2 compares the firm performance and the owner optimism variables across high- and low- overall business friendliness score states. The results of the Mann-Whitney Wilcoxon test are shown in the last column. As we can see from the table, the overall business friendliness score has a statistically significant impact on "Growthinrevenue" (i.e. firm performance) in a state. The median value of the "Growthinrevenue" variable is 2.16 (out of 4) in high-overall score states versus 2.02 in low-overall score states (the p-value of the difference is 0.0045 ). We are also seeing that the overall score has a significant impact on "Growthinemployees" in a state. When we look at the medians, we are seeing that in high-overall score states, the median value of the 
"Growthinemployees" variable is 2.16 (out of 4), while in low-overall score states; the corresponding value is 2.11. The difference is statistically significant ( $\mathrm{p}$-value $=0.0137)$.

Table 2. Comparison of High- and Low-Overall Score States

\begin{tabular}{|l|c|c|c|c|c|}
\hline & \multicolumn{2}{|c|}{ High-Overall Score } & \multicolumn{2}{c|}{ Low-Overall Score } & Mann-W. \\
\hline Variable & Mean & Med. & Mean & Med. & p-value \\
\hline Growthinrevenue & 2.13 & 2.16 & 2.01 & 2.02 & 0.0045 \\
\hline Growthinemployees & 2.17 & 2.16 & 2.11 & 2.11 & 0.0137 \\
\hline Encourageothers & 2.89 & 2.90 & 2.56 & 2.60 & $<0.0001$ \\
\hline Stategovsupport & 2.57 & 2.52 & 2.23 & 2.25 & $<0.0001$ \\
\hline Localgovsupport & 2.65 & 2.63 & 2.40 & 2.43 & $<0.0001$ \\
\hline
\end{tabular}

Source: Author's own work.

When we examine the impact of the overall business friendliness score on owners' optimism measures, we are seeing a significant impact on all three measures. In high-overall score states, the median value of the "Encourageothers" variable is 2.90 (out of 4), while in low-overall score states; the corresponding value is 2.60. The difference is statistically significant (p-value $<0.0001$ ). Similarly, in high-overall score states, the median value of the "Stategovsupport" variable is 2.52 (out of 4), while in low-overall score states; the corresponding value is 2.25 . The difference is statistically significant (p-value $<0.0001$ ). Finally, in high-overall score states, the median value of the "Localgovsupport" variable is 2.63 (out of 4), while in low-overall score states; the corresponding value is 2.43 . The difference is statistically significant ( $p$-value $<0.0001$ ).

Table 3 compares the firm performance and the owner optimism variables across high- and low- "ease of start" score states. As we can see from the table, the "ease of start" score has a statistically significant impact on "Growthinrevenue" (i.e. firm performance) in a state. The median value of the "Growthinrevenue" variable is 2.16 in high-overall score states versus 2.03 in low-score states (the p-value of the difference is 0.0293). On the other hand, the "ease of start" score does not have a statistically significant impact on "Growthinemployees". When we look at the medians, we are seeing that in high- score states, the median value of the "Growthinemployees" variable is 2.16, while in low-score states; the corresponding value is 2.13 . The difference is statistically insignificant (pvalue $=0.3323$ ).

Table 3. The Impact of States' "Ease of Start" Scores

\begin{tabular}{|l|c|c|c|c|c|}
\hline & \multicolumn{2}{|c|}{ High } & \multicolumn{2}{c|}{ Low } & Mann-W. \\
\hline Variable & Mean & Med. & Mean & Med. & p-value \\
\hline Growthinrevenue & 2.12 & 2.16 & 2.03 & 2.03 & 0.0293 \\
\hline Growthinemployees & 2.14 & 2.16 & 2.14 & 2.13 & 0.3323 \\
\hline Encourageothers & 2.86 & 2.88 & 2.60 & 2.61 & $<0.0001$ \\
\hline Stategovsupport & 2.51 & 2.49 & 2.31 & 2.30 & 0.0017 \\
\hline Localgovsupport & 2.60 & 2.58 & 2.47 & 2.47 & 0.0196 \\
\hline
\end{tabular}

Source: Author's own work.

On the other hand, the "ease of start" score has a significant impact on the three owner optimism variables. In high-score states, the median value of the "Encourageothers" variable is 2.88, while in low-score states; the corresponding value is 2.61 . The difference is statistically significant (p-value $<0.0001$ ). Similarly, in highscore states, the median value of the "Stategovsupport" variable is 2.49 , while in low-score states; the corresponding value is 2.30 . The difference is statistically significant ( $p$-value $=0.0017$ ). Finally, in high-score states, the median value of the "Localgovsupport" variable is 2.58 , while in low-score states; the corresponding value is 2.47 . The difference is statistically significant ( $\mathrm{p}$-value $=0.0196$ ).

Table 4 compares the firm performance and the owner optimism variables across high- and low- "ease of hire" score states. As we can see from the table, the "ease of hire" score does not have a statistically significant impact on "Growthinrevenue" in a state. The median value of the "Growthinrevenue" variable is 2.05 in highscore states versus 2.10 in low-score states (the p-value of the difference is 0.3055 ).

The "ease of hire" score also does not have a statistically significant impact on "Growthinemployees". When we look at the medians, we are seeing that in high-score states, the median value of the "Growthinemployees" variable is 2.13 , while in low-score states; the corresponding value is 2.14 . The difference is statistically insignificant ( $\mathrm{p}$-value $=0.4021)$. 
Table 4. The Impact of States" "Ease of Hire" Scores

\begin{tabular}{|l|c|c|c|c|c|}
\hline & \multicolumn{2}{|c|}{ High } & \multicolumn{2}{c|}{ Low } & Mann-W. \\
\hline Variable & Mean & Med. & Mean & Med. & p-value \\
\hline Growthinrevenue & 2.07 & 2.05 & 2.09 & 2.10 & 0.3055 \\
\hline Growthinemployees & 2.14 & 2.13 & 2.15 & 2.14 & 0.4021 \\
\hline Encourageothers & 2.80 & 2.82 & 2.69 & 2.64 & 0.0252 \\
\hline Stategovsupport & 2.52 & 2.52 & 2.33 & 2.39 & 0.0069 \\
\hline Localgovsupport & 2.62 & 2.61 & 2.47 & 2.51 & 0.0252 \\
\hline
\end{tabular}

Source: Author's own work.

On the other hand, the "ease of hire" score has a significant impact on the other three owner optimism variables. In high-score states, the median value of the "Encourageothers" variable is 2.82, while in low-score states; the corresponding value is 2.64 . The difference is statistically significant ( $\mathrm{p}$-value $=0.0252$ ). Similarly, in highscore states, the median value of the "Stategovsupport" variable is 2.52 , while in low-score states; the corresponding value is 2.39 . The difference is statistically significant (p-value $=0.0069$ ). Finally, in high-score states, the median value of the "Localgovsupport" variable is 2.61 , while in low-score states; the corresponding value is 2.51 . The difference is statistically significant ( $\mathrm{p}$-value $=0.0252$ ). Table 5 compares the firm performance and the owner optimism variables across high- and low- "overall regulations" score states. As we can see from the table, the "overall regulations" score does not have a statistically significant impact on "Growthinrevenue" in a state. The median value of the "Growthinrevenue" variable is 2.13 in high-score states versus 2.07 in low-score states (the p-value of the difference is 0.1321 ). On the other hand, we are seeing that the "overall regulations" score has a statistically significant impact on "Growthinemployees" and on all three owner optimism variables.

Table 5. The Impact of States' "Overall Regulations" Scores

\begin{tabular}{|l|c|c|c|c|c|}
\hline & \multicolumn{2}{|c|}{ High } & \multicolumn{2}{c|}{ Low } & Mann-W. \\
\hline Variable & Mean & Med. & Mean & Med. & p-value \\
\hline Growthinrevenue & 2.11 & 2.13 & 2.04 & 2.07 & 0.1321 \\
\hline Growthinemployees & 2.18 & 2.16 & 2.10 & 2.12 & 0.0151 \\
\hline Encourageothers & 2.86 & 2.90 & 2.60 & 2.61 & $<0.0001$ \\
\hline Stategovsupport & 2.53 & 2.49 & 2.28 & 2.31 & 0.0005 \\
\hline Localgovsupport & 2.65 & 2.64 & 2.41 & 2.46 & $<0.0001$ \\
\hline
\end{tabular}

Source: Author's own work.

Finally, Table 6 compares the firm performance and the owner optimism variables across high- and low- "training and networking" score states. As we can see from the table, the "training and networking" score does not have a statistically significant impact on "Growthinrevenue" in a state. The median value of the "Growthinrevenue" variable is 2.11 in high-score states versus 2.05 in low- score states (the p-value of the difference is 0.3769 ).

Table 6. The Impact of States' "Training and Networking” Scores

\begin{tabular}{|l|c|c|c|c|c|}
\hline & \multicolumn{2}{|c|}{ High } & \multicolumn{2}{c|}{ Low } & Mann-W. \\
\hline Variable & Mean & Med. & Mean & Med. & p-value \\
\hline Growthinrevenue & 2.09 & 2.11 & 2.07 & 2.05 & 0.3769 \\
\hline Growthinemployees & 2.16 & 2.16 & 2.12 & 2.13 & 0.1509 \\
\hline Encourageothers & 2.84 & 2.89 & 2.63 & 2.63 & 0.0011 \\
\hline Stategovsupport & 2.50 & 2.46 & 2.33 & 2.34 & 0.0166 \\
\hline Localgovsupport & 2.64 & 2.62 & 2.43 & 2.44 & 0.0011 \\
\hline
\end{tabular}

Source: Author's own work.

The "training and networking" score also does not have a statistically significant impact on "Growthinemployees" variable. The median value of the "Growthinemployees" variable is 2.16 in high-score states versus 2.13 in lowscore states (the p-value of the difference is 0.1509). On the other hand, we are seeing that the "training and networking" score has a statistically significant impact on the three owner optimism variables ("Encourageothers", Stategovsupport", and "Localgovsupport"). Table 7 shows the results of our regressions (equations 1, 2, and 3) where the dependent variable is growth in revenues in columns 2 and 3, growth in employees in columns 4 and 5 , and encourage others in columns 6 and 7. As explained earlier, the independent variables are "highschoolorlower", "ageunderthirtyfive", "female", "primary", "previousentre", "ageofbusfiveormore", "mostlocal", and "overallscore". The "overallscore" variable is our main independent variable which is the business friendliness composite score of each state. 
Table 7. Business Friendliness, Firm Performance and Optimism

\begin{tabular}{|c|c|c|c|c|c|c|}
\hline & \multicolumn{2}{|c|}{ Growthinrevenues } & \multicolumn{2}{|c|}{ Growthinemployees } & \multicolumn{2}{|c|}{ Encourageothers } \\
\hline & Coef. & $\mathrm{P}$-value & Coef. & P-value & Coef. & P-value \\
\hline Intercept & 0.3884 & 0.4784 & 2.0174 & 0.0000 & 3.0661 & 0.0000 \\
\hline Highschoolorlower & -0.0061 & 0.1550 & 0.0011 & 0.7210 & 0.0002 & 0.9517 \\
\hline Ageunderthirtyfive & 0.0125 & 0.0030 & 0.0031 & 0.2737 & -0.0005 & 0.8603 \\
\hline Female & -0.0042 & 0.3140 & -0.0002 & 0.9562 & 0.0035 & 0.2559 \\
\hline Primary & 0.0088 & 0.0150 & 0.0050 & 0.0472 & -0.0048 & 0.0671 \\
\hline Previousentre & 0.0004 & 0.9151 & 0.0001 & 0.9547 & 0.0016 & 0.5321 \\
\hline Ageofbusfiveormore & 0.0063 & 0.0635 & -0.0038 & 0.1104 & -0.0048 & 0.0563 \\
\hline Mostlocal & 0.0058 & 0.1377 & -0.0016 & 0.5634 & -0.0026 & 0.3634 \\
\hline Overallscore & 0.0256 & 0.0006 & 0.0061 & 0.2061 & 0.0485 & 0.0000 \\
\hline R Square & 0.5201 & & 0.2867 & & 0.8515 & \\
\hline
\end{tabular}

Source: Author's own work

The first regression shows that, as expected, "Overallscore" has a positive and significant impact on "growthinrevenues". The coefficient of this variable is $0.0256(\mathrm{p}=0.0006)$. "Ageunderthirtyfive" is also positive and significant (coef. $=0.0125, \mathrm{p}=0.0030$ ). The age of the entrepreneur has a significant impact on "growthinrevenues". The firms that are owned by younger entrepreneurs tend to grow their revenue faster. "Primary" is also positive and significant (coef. $=0.0088, \mathrm{p}=0.0150$ ). The firms that serve as the owner's primary employment tend to grow their revenue faster. "Ageofbusfiveormore" is also positive and significant (coef. $=0.0063, \mathrm{p}=0.0635$ ). The firms that are more established tend to grow their revenue faster. The R-Square value for this model is 0.5201 .

The second regression shows that, after controlling for other variables, "Overallscore" does not have a significant impact on "growthinemployees". The coefficient of this variable is $0.0061 \quad(p=0.2061)$. The only statistically significant variable in this model is "Primary". "Primary" is positive and significant (coef. $=0.0050$, $\mathrm{p}=0.0472$ ). The R-Square value for this model is 0.5201 .

The third regression shows that, as expected, "Overallscore" has a positive and significant impact on "encourageothers". The coefficient of this variable is $0.0485(\mathrm{p}=0.0000)$. "Primary" has a negative and significant impact (coef. $=-0.0048, \mathrm{p}=0.0671$ ). If the business is the primary employment for the owner, he encourages others less. This may be due to the owner spending too much effort and time on the business which would make him less encouraging for others. "Ageofbusfiveormore" also has a negative and significant impact (coef. $=-0.0048, \mathrm{p}=0.0563$ ). More established firms are less encouraging to others compared to newer firms. It seems like, over time, the owner loses his enthusiasm a little bit, therefore encourages others less. The RSquare value for this model is 0.8515 .

\section{Conclusion}

In this study, we attempt to find the factors that influence small business owners' optimism as well as their company's success. For this purpose, we use a survey done by Kauffman foundation. This survey asks business owners about their state's performance in areas like "ease of starting a business", "ease of hiring", "regulations", and "training and networking programs". It also asks business owners questions about their firm's recent performance and their optimism for the future.

For firm performance, we look at the most recent year's revenue increase and the expected growth in the number of employees over the next 12 months. For owner's optimism, we look at three measures: (1) whether owners would encourage others to start a business, (2) whether owners feel that the state is supporting them, (3) whether owners feel that the local government is supporting them. First, we run tests to see if firm performance and owner optimism is higher in states with high overall business friendliness score compared to the states with a low overall score. Our results show that, the overall business friendliness score has a significant impact on both firm performance and owners' optimism (i.e. all five measures).

When we run regressions, we find that the regressions support our earlier findings with nonparametric tests, except for the second model. After controlling for several variables, we find that overall business friendliness score significantly explains both growth in revenue and owner's optimism, but not growth in the number of employees.

Then, we run more detailed tests that look at each subcategory ("ease of starting a business", "ease of hiring", 
"training and networking programs", and "overall regulations"). Our results show that a state's "ease of start" score has a significant impact on "growthinrevenues" as well as on the three optimism measures. However, it does not have a significant impact on "growthinemployees".

We find that a state's "overall regulations" score has a significant impact on "growthinemployees" as well as on the three optimism measures. However, it does not have a significant impact on "growthinrevenues".

We also find that the "ease of hire" and the "training and networking" scores do only affect owners' optimism, but not firm performance.

We conclude that while there is a strong relation between all components of business friendliness and small business owners' optimism, the link between the business friendliness score and firm performance is weaker. Two components of business friendliness, "Ease of hire" and "Training and networking" only affects owner's optimism, but not firm performance. The third component, "Ease of start", affects owners' optimism and only one of the performance measures, which is "growthinrevenue". The fourth component, "Overall regulations", affects owners' optimism and only one of the performance measures, which is "growthinemployees".

Although our results failed to show a significant relationship between each of the components and firm performance (with the exception of "Ease of start" ony affecting "growthinrevenues" and "Overall regulations" only affecting "growthinemployees"), we find that the "Overall score" on business friendliness affects both measures of firm performance and all three measures of optimism. Therefore, we conclude that while no specific component of business friendliness affects firm performance, a state's overall "business friendliness" score significantly affects it.

We conclude that "business friendliness" is important in making business owners more optimistic as well as in improving their performance. In order to improve both the morale and the performance of the small business owners, policymakers need to improve all components of "business friendliness".

Our findings indicate that in the states with a higher business friendliness composite score, both growth in revenue and growth in employees are higher and also owners tend to be more encouraging to others. When we look into the subcomponents, we are seeing that growth in revenue is driven by the Ease of Start score. Therefore, we can conclude that states that want to increase revenues should focus on improving the firm registration/establishment process. In this study, we are also seeing that growth in employees (i.e. the size of the firm) is driven by the Overall Regulations score. We can conclude that states that want to grow small businesses (in terms of number of employees) should focus on improving regulations. On the other hand, our results indicate that all subcomponents (Ease of Start, Ease of Hire, Overall Regulations, and Training and Networking programs) explain whether owners encourage others more or not. Therefore, no subcomponent is dominant here.

The results in this study are also important for entrepreneurs. When they look at different states' scores on Ease of Start, Ease of Hire, Overall Regulations, and Training and Networking programs, they will know how an average small business performs with respect to sales, growth and morale in each state. So, they would know what to expect if they start a business in a certain state. This should affect their decision on where to start their new business.

\section{References}

1. Acs, Z. J., Braunerhjelm, P., Audretsch, D. B., and Carlsson, B. (2009). The knowledge spillover theory of entrepreneurship, Small business economics, 32(1), 15-30. Retrieved from: https://link.springer.com/article/10.1007/s11187-008-9157-3

2. Acs, Z. J., and Szerb, L. (2007). Entrepreneurship, economic growth and public policy, Small business economics, 28 (2-3), 109-122. Retrieved from: https://ink.springer.com/article/10.1007/s11187-0069012-3

3. Aidis, R., Estrin, S., and Mickiewicz, T. (2008). Institutions and entrepreneurship development in Russia: A comparative perspective, Journal of Business Venturing, 23(6), 656-672. https://doi.org/10.1016/j.jbusvent.2008.01.005

4. Aidis, R., Welter, F., Smallbone, D., and Isakova, N., (2007), Female entrepreneurship in transition economies: the case of Lithuania and Ukraine, Feminist Economics, 13(2), 157-183. Retrieved from: http://www.w-t-w.org/en/wp-content/uploads/2014/03/women-entrepreneurs-in-ukraine.pdf

5. Bailey, J.B. and Thomas, D.W. (2017). Regulating away competition: The effect of regulation on entrepreneurship and employment, Journal of Regulatory Economics, 52(3), 237-254. Retrieved from: 
https://www.researchgate.net/profile/James_Bailey3/publication/320656266_Regulating_away_competit ion the effect of regulation_on_entrepreneurship and employment/links $/ 5 \mathrm{~d} 768 \mathrm{bc} 092851 \mathrm{cacdb} 2 \mathrm{de} 470$ Regulating-away-competition-the-effect-of-regulation-on-entrepreneurship-and-employment.pdf

6. Branstetter, L., Lima, F., Taylor, L. J., and Venâncio, A. (2014). Do entry regulations deter entrepreneurship and job creation? Evidence from recent reforms in Portugal, The Economic Journal, 124(577), 805-832. Retrieved from: https://www.nber.org/papers/w16473.pdf

7. Bitzenis, A., and Nito, E. (2005). Obstacles to entrepreneurship in a transition business environment: the case of Albania, Journal of Small Business and Enterprise Development, 12(4), 564-578. Retrieved from: https://www.researchgate.net/profile/Aristidis Bitzenis/publication/231575445 Obstacles to entreprene urship_in_a transition_business environment The case_of_Albania/links/0912f506c9cd81091a000000/ Obstacles-to-entrepreneurship-in-a-transition-business-environment-The-case-of-Albania.pdf

8. Chambers, D., McLaughlin, P.A. and Richards, T. (2018). Regulation, Entrepreneurship, and Firm Size, Mercatus Research Paper. Retrieved from: https://www.researchgate. net/profile/Tyler_Richards/publication/ $32533 \quad 0609$ Regulation Entrepreneurship and Firm Size/links/5bd71d89a6fdcc3a8dae5efd/Regulation-Entrepreneurship-and-Firm-Size.pdf

9. Constanta, E. (2019). Holiday vouchers - Essential support for Romanian tourism, Annals - Economy Series, 6, 56-61. Retrieved from: http://www.utgjiu.ro/revista/ec/pdf/2019-06/08 EneaC.pdf

10. Deakins, D., Bensemann, J. and Battisti, M., (2016). Entrepreneurial skill and regulation, International Journal of Entrepreneurial Behavior \& Research. Retrieved from: https://eprints.lancs.ac.uk/id/eprint/80136/1/Author_accepted_manuscript.pdf

11. Douglas, J. and Pejoska, A.L., (2017), Regulation and small business, Economic Round-up, 1. Retrieved from: https://treasury.gov.au/sites/default/files/2019-03/p2017-t213722-Roundup_Sml_bus_regulationfinal.pdf

12. Dreher, A., and Gassebner, M. (2013). Greasing the wheels? The impact of regulations and corruption on firm entry, Public Choice, 155(3-4), 413-432. Retrieved from: https://link.springer.com/content/pdf/ 10.1007/s11127-011-9871-2.pdf

13. García-Posada, M., and Mora-Sanguinetti, J. S. (2015). Entrepreneurship and enforcement institutions: Disaggregated evidence for Spain, European Journal of Law and Economics, 1-26. Retrieved from: https://search.proquest.com/openview/0436d1c95682cae2081fbad93eb8b588/1.pdf/advanced

14. Gartner, W. B., and Shane, S. A. (2014). Measuring entrepreneurship over time, Regional Studies, 48(6), 1071-1089. https://doi.org/10.1016/0883-9026(94)00037-U

15. Ghani, E., Kerr, W. R., and O'Connell, S. (2014). Spatial determinants of entrepreneurship in India, Regional Studies, 48(6), 1071-1089. Retrieved from: https://www.nber.org/papers/w17514.pdf

16. Klapper, L., Laeven, L., and Rajan, R. (2006). Entry regulation as a barrier to entrepreneurship, Journal of Financial Economics, 82(3), 591-629. Retrieved from: http://citeseerx.ist.psu.edu/viewdoc/ download?doi $=10.1 \cdot 1.576 .1585 \&$ rep $=$ rep1\&type $=$ pdf

17. Manolova, T. S., Eunni, R. V., and Gyoshev, B. S. (2008). Institutional environments for entrepreneurship: Evidence from emerging economies in Eastern Europe, Entrepreneurship Theory and Practice, 32(1), 203-218. https://doi.org/10.1111/j.1540-6520.2007.00222.x

18. Nawaser, K., Khaksar, S. M. S., Shaksian, F., and Jahanshahi, A. A. (2011). Motivational and legal barriers of entrepreneurship development, International Journal of Business and Management, (6)11, 112.

19. Nyström, K. (2008). The institutions of economic freedom and entrepreneurship: evidence from panel data, Public Choice, 136(3-4), 269-282. https://www.jstor.org/stable/ pdf/40270760.pdf?casa token=rK2F4FMVa6sAAAAA:eiEnF yRpseVoiMZXLHJfjKz6Y-KoA uY41 BOLvuQpTt2nF85ipHrVJRDjw80jL6KevgjavzpMZiLW9VW3PCUS Gi7BJy-7xAxNWp 1ErdkaAELUSE

20. Ovaska, T., and Sobel, R. S. (2005). Entrepreneurship in post-socialist economies, Journal of Private Enterprise, 21(1), 8-28. Retrieved from: https://econpapers.repec.org/RePEc:jpe:journl:811

21. Parker, S. C. (2007). Law and the Economics of Entrepreneurship, Comparative Labor Law \& Policy Journal, 28(4). Retrieved from: https:/heinonline.org/HOL/Page?handle=hein.journals/cllpj 28\&div=46\&g_sent $=1 \&$ casa token=IRetXbXtu6QAAAAA:rMK-3PCD5mpv1 qlzb7qdtSTy0g_2qo Vkxyvlz4dp2Sqha RbUO yypRdClecNX9uAldHAaWMPXA\&collection=journals

22. Peck, F., Jackson, K. and Mulvey, G. (2018). Regulation and growth-oriented small businesses in NorthWest England, Journal of Small Business and Enterprise Development. Retrieved from: http://insight.cumbria.ac.uk/id/eprint/3552/1/Peck_RegulationAndGrowth.pdf 
23. Smallbone, D., Welter, F., Voytovich, A., and Egorov, I. (2010). Government and entrepreneurship in transition economies: the case of small firms in business services in Ukraine, The service industries Journal, 30(5), 655-670. Retrieved from: https://www.tandfonline.com/doi/abs/ 10.1080/ 02642060802253876

24. Sobel, R. S., Clark, J. R., and Lee, D. R. (2007). Freedom, barriers to entry, entrepreneurship, and economic progress, The Review of Austrian Economics, 20(4), 221-236. Retrieved from: http://faculty.citadel.edu/sobel/All $\% 20 \mathrm{Pubs} \% 20 \mathrm{PDF} /$ Freedom, $\% 20$ Barriers $\% 20$ to $\% 20$ Entry, $\% 20$ Entrepr eneurship.pdf

25. Stephan, U., and Uhlaner, L. M. (2010). Performance-based vs socially supportive culture: A crossnational study of descriptive norms and entrepreneurship, Journal of International Business Studies, 41(8), 1347-1364. Retrieved from: https://publications.aston.ac.uk/id/eprint/21180/ $1 /$ Performance based vs socially supportive culture.pdf

26. Valdez, M. E., and Richardson, J. (2013). Institutional Determinants of Macro-Level Entrepreneurship, Entrepreneurship Theory and Practice, 37(5), 1149-1175. Retrieved from: https://journals.sagepub.com /doi/abs/10.1111/etap.12000

27. Van Stel, A., Storey, D. J., and Thurik, A. R. (2007). The effect of business regulations on nascent and young business entrepreneurship, Small Business Economics, 28(2-3), 171-186. Retrieved from: https://link.springer.com/content/pdf/10.1007/s11187-006-9014-1.pdf

28. Wennekers, S., and Thurik, R. (1999). Linking entrepreneurship and economic growth, Small business economics, 13(1), 27-56. Retrieved from: https://www.researchgate.net/publication/5157982 Linking_Entrepreneurship_and_Economic_Growth 